DOI: $10.19195 / 0137-1134.110 .5$

\author{
GRAŻYNA SKĄPSKA
}

Uniwersytet Jagielloński

\title{
OD „LEGALNEJ REWOLUCJI” DO KONTRREWOLUCJI. KRYZYS KONSTYTUCJONALIZMU LIBERALNO-DEMOKRATYCZNEGO W POLSCE
}

Punktem wyjścia tego tekstu są dwie konstatacje empiryczne. Pierwsza z nich dotyczy tempa zmian — błyskawicznego demontażu porządku liberalno-demokratycznego, budowanego w Polsce od 1989 roku. Jak się okazało, w rok od wyborów parlamentarnych zakwestionowany został nie tylko dorobek instytucjonalny ostatnich 27 lat, nie tylko porozumienia, które były źródłem instytucji tworzących nowy porządek, lecz także ideowe i aksjologiczne podstawy tego porządku. Druga teza dotyczy dogłębnego i całościowego charakteru owych zmian — w zaskakująco szybkim tempie ograniczono uprawnienia Trybunału Konstytucyjnego, a zatem instytucji kluczowej dla funkcjonowania współczesnych liberalnych demokracji, dla realizacji zasady rządów prawa w jej współczesnym rozumieniu, kontroli konstytucyjności tworzonych przez Parlament ustaw, ochrony fundamentalnych praw obywatelskich i trójpodziału władz oraz instytucji, dzięki której możliwe jest kształtowanie konsensusu i racjonalizacja porządku społecznego we współczesnym, pluralistycznym społeczeństwie. Kolejne kroki w procesie demontażu, a nawet destrukcji, wyznaczają szybko po sobie uchwalane ustawy dotyczące funkcjonowania mediów publicznych, policji, służby cywilnej, prokuratury, obrotu gruntami rolnymi oraz ustawy dotyczące wymiaru sprawiedliwości, w tym przede wszystkim sądownictwa i zasad jego organizacji oraz samorządu sędziowskiego - Krajowej Rady Sądownictwa. Zmiany zarówno już dokonane, jak i planowane niosą ograniczenie obywatelskich praw podstawowych, niezależności mediów publicznych, apolityczności i merytoryczności służby cywilnej, ochrony danych, praw własności oraz przyszłości niezawisłości sędziów, a zatem ograniczenie tych praw i wolności obywatelskich oraz zasad, które stanowią o istocie współczesnego porządku liberalno-demokratycznego. Z kolei ustawy dotyczące funkcjonowania służby cywilnej godzą w podstawy zarządzania państwem.

Odchodzenie od zasad demokracji liberalnej ma miejsce w wielu krajach Europy Środkowo-Wschodniej. Kilka już lat temu w opublikowanej książce Jacques 
Rupnik i Jan Zielonka zauważyli, iż gdy kraje tego regionu stawały się członkami Unii Europejskiej w latach 2004-2007, były one oceniane jako skonsolidowane demokracje, funkcjonujące na podstawie zasad konstytucjonalizmu oraz rządów prawa, z działającą administracją oraz funkcjonującym rynkiem. Obecna rzeczywistość daleko odbiega od tych optymistycznych ocen ${ }^{1}$. Kształtujące się w tych krajach systemy określane są, lub same się określają, jako demokracje nieliberalne, suwerenne, sterowane, statystyczne lub autorytarne, co odnosi się do zawładnięcia instytucji państwowych przez większości parlamentarne².

Szczególnym przykładem jest tu Polska a także Węgry, pionierzy procesu pokojowego odrzucenia komunizmu oraz swego czasu inicjatorzy nowatorskich rewolucji „legalnych”, a zatem przeprowadzonych w ramach obowiązującego prawa i z poszanowaniem jego procedur ${ }^{3}$. W Polsce, w sposób jeszcze bardziej charakterystyczny niż na Węgrzech, destrukcja konstytucjonalizmu i zasad demokracji liberalnej odbywa się błyskawicznie, całościowo, brutalnie i cynicznie: prokuratorzy stanu wojennego są przewodniczącymi sejmowej komisji praw człowieka oraz faktycznymi twórcami ustaw o Trybunale Konstytucyjnym, prezesem Trybunału Konstytucyjnego zostaje magister prawa-sędzia sądu rejonowego, uchwalanie fundamentalnych ustaw, jak ustawa budżetowa na przyszły rok, odbywa się z pogwałceniem procedur (kworum, podpisy na listach, głosowanie poprawek w blokach) i wykluczeniem opozycji. Odbieranie opozycji prawa do głosu staje się stałą praktyką parlamentarną. Brutalność i cynizm są przy tym zupełnie niepotrzebne, gdyż mając większość parlamentarną, wystarczającą do uchwalania ustaw, rządząca koalicja partii prawicowych mogłaby uchwalić każde prawo, bez konieczności łamania procedur czy poniżania godności byłego już prezesa Trybunału Konstytucyjnego, sędziów Trybunału, sędziów w ogólności oraz posłów opozycji. Politycznym narzędziem owej destrukcji liberalno-demokratycznego konstytucjonalizmu staje się swoiście, czysto instrumentalnie rozumiane prawo. Celem tego artykułu jest zatem opisanie mechanizmów oraz podjęcie próby odpowiedzi na pytanie o czynniki, które powodują tak dramatyczne zmiany, tak zdecydowane i gwałtowne odejście od pryncypiów, które niecałe 30 lat temu zadecydowały o sukcesie tzw. pokojowych rewolucji, będących także „rewolucjami legalnymi”.

1 J. Rupnik, J. Zielonka, Introduction: The state of democracy 20 years on: Domestic and external factors, „East European Politics and Societies and Cultures”27, 2013, nr 1.

2 Ibidem; por. także V. Ganev, Post-accession hooliganism: Democratic governance in Bulgaria and Romania after 2007, „East European Politics and Societies” 27, 2013, nr 1; I. Guardianchich, The uncertain future of Slovenian exceptionalism, „East European Politics and Societies” 26, 2012, nr 2; B. Bugarić, A crisis of constitutional democracy in post-communist Europe: ,land in between”, democracy and authoritarianism”, „International Journal of Constitutional Law” 13, 2016, s. 219-245.

3 G. Skąpska, From „Civil Society” to „Europe”. A Sociological Study on Constitutionalism after Communism”, Leiden-Boston 2011. 
W pierwszej części tego artykułu przedstawię koncepcje rewolucji legalnych i wskażę na ich istotną cechę, która niosła zapowiedź szczególnych ich skutków. Następnie pokrótce opiszę mechanizmy kontrrewolucji realizowanej przy pomocy prawa, a jednocześnie z jego pogwałceniem. Przedmiotem tego opisu będą wydarzenia w Polsce poprzedzone jednak krótką relacją wydarzeń na Węgrzech, m.in. ze względu na to, iż Węgry stanowią rodzaj modelu do naśladowania według deklaracji polskich polityków. Kolejno, scharakteryzuję zjawisko tzw. powodzi prawnej, w istotny sposób naruszającej moralność prawa, wskazującej jednocześnie na czysto instrumentalne, a zarazem nihilistyczne jego traktowanie. W końcowej debacie, a zatem w czwartej części tego artykułu, scharakteryzuję szczególną lukę aksjologiczną, jako istotny kontekst obecnych kontrrewolucji. W świetle tezy niniejszego artykułu kontekst ten stanowi źródło hipotez wyjaśniających drogę od legalnych rewolucji do destrukcji rządów prawa, od legalizmu do nihilizmu prawnego.

\section{1. „LEGALNE REWOLUCJE”}

Termin „rewolucje legalne” został użyty po raz pierwszy w odniesieniu do wydarzeń, jakie miały miejsce na Węgrzech w roku $1989^{4}$. Zgodnie ze spostrzeżeniem autora tego terminu, pomimo głębokich zmian ustrojowych, obowiązujące wówczas prawo nie zostało tam nawet przez moment zakwestionowane ${ }^{5}$. Przestrzeganie prawa było jednym z postulatów węgierskiego „Okrągłego Stołu” i porozumień zawartych pomiędzy opozycją i przedstawicielami ówczesnej „strony rządowej”, a zatem węgierskiej partii komunistycznej. Podobnie w Polsce zmiany ustrojowe dokonywały się w ramach obowiązującego prawa, a prawo oraz nowe instytucje kształtowane były zgodnie z procedurami regulującymi zmiany prawa i stanowienia nowego ${ }^{6}$. Na legalność przemian ustrojowych w ówczesnej Czechosłowacji zwracają uwagę tamtejsi autorzy ${ }^{7}$. Te „legalne rewolucje” były zapocząt-

4 Termin „legalne rewolucje” użyty był po raz pierwszy przez autorów węgierskich, w tym przede wszystkim przez znanego opozycjonistę oraz uczestnika węgierskiego „okrągłego stołu” Jánosa Kisa. Por. idem, Between reforms and revolution: Three hypotheses about the nature of the regime change, [w:] Lawful Revolutions in Hungary 1989-199, red. B.K. Kidaly, A. Bozoki, Colorado 1995. Opinia o legalności rewolucji na Węgrzech była następnie mocno poparta przez László Sólyoma, wówczas prezesa Sądu Konstytucyjnego na Węgrzech, który podkreślił pewność i stałość jako główne cechy węgierskiej drogi do demokracji. Również czechosłowacka strategia przemian została określona jako „legalistyczna” (por. J. Přibáň, Dissidents of Law. On the 1989 Velvet Revolutions, Legitimations, Fictions of Legality and Contemporary Version of the Social Contract, Darthmouth 2002, s. 47, podobnie jak polska, por. G. Skąpska, op. cit., s. 38 n.

5 J. Kis, op. cit., s. 34; L. Sólyom, The Role of Constitutional Courts in the transition to democracy, with special reference to Hungary, „International Sociology”18, 2003, nr 1, s. 7.

${ }^{6}$ G. Skąpska, op. cit., s. 26 n.

7 J. Přibáň, op. cit., s. 34. 
kowane przez tzw. porozumienia Okrągłych Stołów, a wszelkie nawoływania do złamania owych porozumień, jak w Polsce, gdy okazało się, iż opozycja odniosła spektakularne zwycięstwo w pierwszych wyborach parlamentarnych, były odrzucane z powodu respektowania zasady pacta servanda sunt, a zatem fundamentalnej zasady, na której wspiera się prawo, nawet jeśli nie została ona zapisana. Jak wówczas podkreślałam, ówcześni zwycięzcy wyborów, byli opozycjoniści, głosili hasło poszanowania prawa, nawet za cenę spadku popularności, co rzeczywiście szybko nastąpiło — nie tylko na skutek ich legalizmu ${ }^{8}$.

Rewolucje legalne, które umożliwiły pokojowy demontaż systemu totalitarnego, charakteryzowały się wysokim poziomem samoograniczania przez partnerów porozumień, co znajdowało poparcie wewnętrzne i zewnętrzne. Ani w Polsce, ani na Węgrzech, ani w ówczesnej Czechosłowacji, Bułgarii, na Litwie, Łotwie czy Estonii społeczne reakcje nie polegały na chęci odwetu, nie było aktów terroru, plądrowania sklepów czy niszczenia mienia publicznego. Zamiast tego były róże na ulicach Pragi. Jedyny wyjątek stanowił tu pokazowy proces oraz egzekucja małżeństwa Ceausescu w Rumunii.

Rewolucje legalne miały swoje cechy zasadnicze. Pierwszą z nich, jak wspomniano, było dochowanie procedur zmiany prawa, tworzenia prawa nowego oraz dokonywania zmian ustrojowych zgodnie z procedurami już istniejącymi lub legalnie wprowadzonymi. Druga to konieczna zmiana konstytucji: we wszystkich tzw. nowych demokracjach zmiany te polegały przede wszystkim na umieszczeniu w konstytucjach zasady rządów prawa i nadaniu jej znaczenia naczelnej (często wprowadzającej) normy konstytucyjnej. Konsekwencją „rewolucji legalnych” oraz uznania zasady państwa prawa za naczelną normę konstytucyjną było między innymi podporządkowanie obowiązującemu prawu rozliczenia komunistycznej przeszłości, a zatem ukarania winnych łamania praw człowieka oraz pogwałcenia praw własności indywidualnej przez reżimy komunistyczne. Na ogół, z wyjątkiem Czechosłowacji, a później Republiki Czeskiej, rozliczenia te podporządkowano literalnie i prawno-pozytywistycznie traktowanej zasadzie państwa prawa, co prowadziło do przewlekłości postepowań przeciwko sprawcom, nieukaraniu winnych, wykorzystywaniu wszelkich kruczków prawnych przez sprawców i ich obrońców w celu uniknięcia odpowiedzialności, zachowania wszelkich przywilejów (np. emerytalnych), jako praw nabytych, przez sprawców łamania praw ludzkich, funkcjonariuszy dawnego systemu. W państwach Europy Środkowo-Wschodniej, ze wspomnianym wyjątkiem dawnej Czechosłowacji oraz dawnej Niemieckiej Republiki Demokratycznej, która stała się częścią Republiki Federalnej Niemiec, nie uznano zatem, iż dokonując głębokich przemian, społeczeństwa powinny zmierzyć się z własną przeszłością, w tym przede wszystkim dokonać ukarania winnych łamania praw człowieka, zgodnie z koncepcją sprawiedliwości

8 G. Skąpska, The rule of law from the East Central European perspective, „Law and Social Inquiry" 1990, nr 15, s. 699-701. 
okresu przemian (transitional justice), a zatem wprowadzenia na okres przejściowy takich instytucji i rozwiązań, które umożliwiłyby ukaranie winnych, a niekiedy, jak w Republice Południowej Afryki, prowadziły do zasypania społecznych podziałów ${ }^{9}$, wiążąc interpretację zasady państwa prawnego z doświadczeniami Polaków oraz uzasadnionym poczuciem krzywdy ${ }^{10}$. Wzbudzało to, i nadal wzbudza, krytyczne reakcje społeczne, ponieważ narusza społeczne poczucie sprawiedliwości. Pominięta bowiem zostaje cała sfera społecznych emocji związanych z doznanymi krzywdami, pominięte zostają odczucia moralne dużej części społeczeństwa $^{11}$. Wielkie emocje społeczne w Polsce wzbudza proces reprywatyzacji, m.in. ze względu na to, iż obowiązujące prawo, przy braku ustawy reprywatyzacyjnej, umożliwiało wykorzystanie go niezgodnie z jego przeznaczeniem, a zatem przejmowanie znacjonalizowanej własności w taki sposób, iż niekiedy drastycznie gwałcone były prawa pierwotnych właścicieli — ofiar komunistycznej nacjonalizacji własności ${ }^{12}$. W pierwszym i drugim wypadku odium społecznej krytyki spada na wymiar sprawiedliwości.

Rewolucje legalne, stanowiąc wyraz uznania dla wielkiej wartości prawa oraz zasady rządów prawa (do czego dołączyła wartość ochrony praw człowieka, głoszona przez ówczesną demokratyczną opozycję), miały zatem doniosłe pozytywne konsekwencje: podporządkowały proces głębokich, rewolucyjnych przemian ustrojowych regułom przewidywalnym i w miarę pewnym. A zatem pewność i przewidywalność oraz literalna interpretacja prawa stanowiły głębokie, aksjologiczne podłoże dokonujących się przemian. Rewolucje legalne miały jednak również negatywne konsekwencje — ścisłe trzymanie się litery obowiązującego wówczas

9 R. Teitel, Transitional Justice, Oxford 2002.

$10 \mathrm{Na}$ kwestię przemocy symbolicznej elit w debacie nad interpretacją zasady państwa prawa w odniesieniu do kwestii lustracji zwraca uwagę w znakomitej analizie dyskursu publicznego Maria Barańska. Por. eadem, Zasada państwa prawnego jako element przetargowy w dyskursie politycznym na temat lustracji, „Studia Socjologiczne” 183, 2007, nr 2, s. 83-116.

11 Na krytyczne oceny społeczne nierozliczenia przeszłości w postaci nieukarania lub ukarania winnych niewspółmiernie do winy wskazują dane dotyczące nieukończenia lub przewlekłości spraw, np. kopalni „Wujek”, zabójstwa księdza Popiełuszki, a zatem spraw zapadających w społeczną pamięć. Por. K. Daniel, Normatywny i społeczny obraz sędziego, [w:] M. Borucka-Arctowa, K. Palecki, Sady w opinii społeczeństwa polskiego, Kraków 2003, s. 124. Całkiem niedawne dane z badań przeprowadzonych w roku 2009 wskazują, iż niezakończone sprawy kopalni „Wujek”, sprawa zabójstwa Grzegorza Przemyka są wymieniane przez respondentów jako najważniejsze. Por. G. Skąpska, G. Bryda, Empirically grounded rule of law, [w:] Sociologies of Formality and Informality, red. A. Mica, J. Winczorek, R. Wiśniewski, Warszawa 2015, s. 43.

12 Kwestia reprywatyzacji stała się ostatnio paląca, jednak nie jest ona nowa. Na szczególne podkreślenie zasługuje, iż niezależnie od braku powszechnej ustawy reprywatyzacyjnej, regulującej całościowo trudne kwestie zadośćuczynienia za znacjonalizowane mienie, samo pojęcie „reprywatyzacja" wskazuje, że kwestie zwrotu mienia właścicielom lub wypłaty ewentualnych odszkodowań były rozpatrywane w kontekście procesów prywatyzacji mienia państwowego, a nie w kontekście fundamentalnych praw własności osób, którym te prawa odebrano. Stąd wielkie rozgoryczenie byłych właścicieli. 
prawa, przy braku pewnej odwagi politycznej do rozliczenia przeszłości oraz dość aroganckim potraktowaniu społecznych oczekiwań związanych z łamaniem praw człowieka i podstawowych wolności, społecznego poczucia krzywdy i niesprawiedliwości, doprowadzało do tego, że przeszłość zaczęła rzutować na przyszłość, tworząc swoiste paradoksy transformacji: gwarancje procesowe były wykorzystywane przez winnych zbrodni łamania praw człowieka, co prowadziło do przewlekłości postępowań i stało się przyczyną krytycznej oceny wymiaru sprawiedliwości w opinii publicznej ${ }^{13}$. Wykorzystywanie kruczków prawnych (niezależnie od wszelkich form działania bezprawnego) doprowadziło do przekazywania mienia wielkiej wartości osobom, które potrafiły wykorzystać prawo zgodnie ze swoim interesem, łamiąc wszelkie roszczenia byłych właścicieli, użytkowników mienia (np. lokatorów) oraz Skarbu Państwa. Osobny problem stanowiła legalizacja swoistego zawłaszczenia własności państwowej przez uprzywilejowane kategorie obywateli — tych, którzy ze względu na pełnione funkcje lub zajmowane stanowiska w poprzednim systemie nomenklatury (w PZPR, przemyśle i handlu państwowym, MO, SB) uzyskali, na mocy uprzednio obowiązujących ustaw, posiadanych zasobów, dostępu do informacji oraz powiązań politycznych i gospodarczych, wielkie prawa dostępu do prywatyzowanej własności. Zgodnie z nowym porządkiem konstytucyjnym te prawa dostępu do przekształceń własności państwowej w własność prywatną stały się konstytucyjnie chronionymi prawami własności zgodnie z fundamentalnym rozumieniem liberalno-demokratycznego konstytucjonalizmu. Z kolei nieodebranie przywilejów (interpretowanych jako prawa nabyte) wzbudziło społeczne poczucie niesprawiedliwości nowego porządku.

Jak się zatem podkreśla, w odniesieniu do kwestii rozliczenia się z komunistyczną przeszłością, w tym kwestii lustracji, zasada państwa prawnego, jako zasada nieostra, może stać się „mieczem obosiecznym”, którym mogli posługiwać się zarówno zwolennicy rozliczeń oraz lustracji w imię sprawiedliwości okresu przemian, jak i przeciwnicy ${ }^{14}$. W opracowaniu poświęconym analizie debaty publicznej nad lustracją, nawiązującym do teorii przemocy symbolicznej elit Pierre'a Bourdieu i teorii „pastoralnego dyskursu” Michela Foucault, jego autorka podkreśla, iż język używany przez elity w dyskursie publicznym miał charakter represyjny, wykluczający inne niż akceptowane przez owe elity rozumienie zasady państwa prawa ${ }^{15}$.

Rewolucje uporządkowały proces przemian i poddały go procedurom zdefiniowanym w obowiązującym prawie. Niestety, czysto literalna wykładnia tego prawa, przy braku odwagi zmierzenia się z własną przeszłością i wyobraźni dotyczącej społecznych tego skutków, spowodowała, iż przemianom ustrojowym w Europie Środkowo-Wschodniej zabrakło momentu zdecydowanego odcięcia się, zdecydo-

13 K. Daniel, op. cit.

${ }_{14}$ M. Barańska, op. cit., s. 84.

15 Ibidem. 
wanego odróżnienia się od przeszłości - winni nie zostali ukarani lub ukarano ich zbyt późno, własność w dużej liczbie przypadków nie wróciła do pierwotnych właścicieli, członkowie dawnej nomenklatury uwłaszczyli się na własności państwowej, a sprawcy zbrodni (tacy jak np. była stalinowska prokurator Wolińska) zachowali swoje emerytalne przywileje.

Konkludując, należy jednak podkreślić, że rewolucje legalne miały swoje niewątpliwe uzasadnienie aksjologiczne w postaci wartości związanych z pewnością i przewidywalnością prawa, również w odniesieniu do fundamentalnych praw i wolności.

Obecnie, po blisko 30 latach od tamtych wydarzeń, obserwujemy swoisty backlash w odniesieniu do całokształtu przemian. To, co było oceniane jako niezaprzeczalne osiągnięcia - demokracja, rządy prawa, demokratyczno-liberalny konstytucjonalizm, ochrona praw obywatelskich, demokratyczne procedury tworzenia i stosowania prawa, niezawisłość sędziowska - stało się przedmiotem ataku parlamentarnych większości, wyłonionych w drodze demokratycznych wyborów. Atak ten jest zdecydowany i brutalny. Ilustruje on fakt, iż czysto formalnie rozumiane prawo czy zasada rządów prawa, podobnie jak czysto statystycznie rozumiana demokracja (jako rządy statystycznej większości parlamentarnej, co w Polsce oznacza rządy reprezentacji ok. 19\% uprawnionych do głosowania), gdy nie są zakorzenione w systemie wartości i norm pozaprawnych tworzących zaplecze kulturowe liberalno-demokratycznego konstytucjonalizmu, stają się łatwym łupem osób i zbiorowości dążących do zdobycia i utrzymania władzy.

\section{DEMONTAŻ KONSTYTUCJONALIZMU — ILUSTRACJA EMPIRYCZNA HIPOKRYZJI PRAWNEJ I PRAWNO-AKSJOLOGICZNEGO NIHILIZMU}

Atak na liberalno-demokratyczny konstytucjonalizm miał miejsce w Azerbejdżanie, Gruzji czy na Białorusi. Przykładem demontażu liberalno-demokratycznego konstytucjonalizmu w Europie Środkowo-Wschodniej przez demokratycznie wybrane większości parlamentarne są Węgry, a także Polska, swego czasu pionierzy demokratycznych przemian, inicjatorzy „legalnych rewolucji”. Przykład Węgier jest tutaj o tyle znaczący, o ile według deklaracji politycznych oraz podejmowanych działań politycznych jest to wzorzec dla przemian dokonujących się w Polsce. Jednak wydarzenia i procesy, jakie zachodzą w tych krajach, charakteryzują znaczne podobieństwa, ale też istotne różnice. Podobieństwem jest wzrastająca, coraz bardziej realna groźba rządów autorytarnych, populistyczna polityka oraz daleko idące ograniczanie zasad i swobód demokratyczno-liberalnych oraz instytucji stojących na straży tych zasad i swobód. Wydarzenia na Węgrzech mają jednak znacznie większą legitymizację niż to, co dzieje się w Polsce. Działania 
podejmowane przez władze na Węgrzech, w tym też reakcja władz węgierskich na zalecenia instytucji europejskich czy Komisji Weneckiej, można określić jako prawną hipokryzję, podczas gdy to, co dzieje się w Polsce, w coraz większym stopniu nosi znamiona aksjologiczno-prawnego nihilizmu ${ }^{16}$.

Należy więc podkreślić iż, w przeciwieństwie do Polski, w wyborach w roku 2010 obecnie rządząca na Węgrzech partia Fidesz wraz z koalicjantem - Koalicją Chrześcijańsko-Demokratyczną — zdobyła konstytucyjną większość w parlamencie węgierskim (w postaci dwóch trzecich miejsc). Frekwencja na Węgrzech wyniosła $64,4 \%$ uprawnionych do głosowania. A zatem partia rządząca, przy znacznej frekwencji wyborczej, zdobyła większość pozwalającą na wprowadzenie zmian do już istniejącej konstytucji oraz uchwalenie nowej. Mimo wszystko jednak, jak się wskazuje, również na Węgrzech parlamentarna większość zastosowała pewien manewr czy też kruczek prawny po to, by nowa konstytucja została uchwalona w takim kształcie, jaki zakładała partia rządząca ${ }^{17}$.

W Polsce dramatyczne zmiany polityczne rozpoczęły się wraz z wyborami prezydenckimi 10 maja 2015 roku. Poparcie kandydatury, a w konsekwencji zwycięstwo obecnego Prezydenta Rzeczypospolitej Polskiej, Andrzeja Dudy, było minimalnie wyższe niż poparcie kontrkandydata, ustępującego prezydenta Bronisława Komorowskiego. Dla przypomnienia, w wyborach prezydenckich Andrzej Duda zdobył 51,55\% głosów, a Bronisław Komorowski 48,45\% głosów wyborców.

Inaczej niż na Węgrzech, zwycięska partia Prawo i Sprawiedliwość wraz z koalicjantami zdobyła w wyborach parlamentarnych 25 października 37,52\% głosów (a poprzednio rządząca Platforma Obywatelska - 24,09\% głosów). Biorąc pod uwagę, iż w wyborach uczestniczyło 50,92 \% elektoratu, zwycięskie PiS (wraz z koalicjantami) poparło około 19\% uprawnionych do głosu Polaków. Należy jednak podkreślić, iż partia rządząca cieszy się niezmiennym poparciem ponad 30\% (oscylującym między 31-47\%) Polaków. Do parlamentu weszły jeszcze Polskie Stronnictwo Ludowe (poparcie 5,13\%), Ruch Kukiz 15' (poparcie 8,81\%) oraz partia Nowoczesna (poparcie 7,60\%) .

16 Część opracowania odnosząca się do sytuacji na Węgrzech opiera się w głównej mierze na analizach skupionych wokół pytania, czy na Węgrzech już doszło do przekształcenia demokracji w rodzaj autorytaryzmu, czy raczej jest to kryzys konstytucjonalizmu. Por. P. Sonnevend, A. Jakab, L. Csink, The constitution as an instrument of everyday politics: The basic law in Hungary, [w:] Constitutional Crisis in the European Constitutional Area. Theory, Law and Politics in Hungary and Romania, red. A. von Bogdany, P. Sonnevend, Oxford 2015; M. Bankuti, G. Halmai, K.L. Scheppele, From separation of powers to a Government without Checks: Hungary's Old and New Constitutions, [w:] G.A. Toth, Constitution for a Disunited Nation, on Hungary's 2011 fundamental law, Budapest 2012. Por. także A. Rixer, Features of the Hungarian Legal System after 2010, Budapest 2012.

17 Jak wskazują cytowani tu autorzy, pierwszy manewr czy też kruczek polegał na uchwaleniu pewnych przepisów jako przejściowych, a potem wprowadzeniu ich na stałe do konstytucji. Opis manewru zastosowanego na Węgrzech w: P. Sonnevend, A. Jakab, L. Csink, op. cit. 
Mając wspomniane poparcie 37,52\% uczestników wyborów, Prawo i Sprawiedliwość jest w stanie uchwalić samodzielnie każdą ustawę, nie ma jednak, inaczej niż Fidesz na Węgrzech, większości konstytucyjnej.

Oceniając sytuację na Węgrzech, można sformułować tezę o wzrastającym autorytaryzmie ${ }^{18}$ lub raczej o kryzysie porządku liberalno-demokratycznego ${ }^{19}$. Zarówno jednak reprezentanci tezy o autorytaryzmie, jak i o kryzysie podkreślają widoczny proces destrukcji konstytucjonalizmu i rządów prawa, co na Węgrzech polega na ciągłych zmianach konstytucji, stopniowej erozji gwarancji ochrony praw podstawowych i demontażu zasady checks and balances. Wskaźnikiem permanentnej zmiany konstytucji jest osiem poprawek do konstytucji z 1989 roku oraz pięć poprawek do nowej ustawy zasadniczej - nowej konstytucji z roku 2011, proklamowanej przez te same partie, które obecnie wprowadzają poprawki. Jak się podkreśla, poprawki te służą realizacji celów politycznych, są one podyktowane doraźnymi interesami partyjnymi, a konstytucja staje się instrumentem w walce o władzę i jej utrzymanie. W związku z tym konstytucja Węgier traci trwałość i pewność konieczną do spełniania roli najważniejszego prawa w państwie ${ }^{20}$, w ten sposób godząc $\mathrm{w}$ wartości pewności i przewidywalności. W charakterystyczny sposób w konstytucji zagwarantowane są podstawowe prawa, a sama konstytucja nie wykracza poza standardy konstytucjonalizmu europejskiego, jednak wprowadzenie szczególnych wyjątków w ochronie podstawowych praw prowadzi do erozji ich ochrony. Jest to szczególnie widoczne w zakresie wolności wyznania w związku z uznaniem kościołów, wolności głoszenia poglądów w związku z prawami i wolnościami indywidualnymi oraz prawami własności w związku z retroaktywnym opodatkowaniem. Proces erozji ochrony praw obywatelskich wynika z naruszenia zasady checks and balances, jest też skutkiem odstąpienia od pełnej realizacji zasady niezawisłości sędziowskiej w związku z problematyczną reorganizacją sądownictwa, wymuszonym przejściem na emeryturę sędziów oraz realokacją postępowań. Co więcej, ponieważ w demokracji parlamentarnej najważniejszą przeciwwagą dla parlamentu jest sąd konstytucyjny, a węgierski Sąd Konstytucyjny został poważnie osłabiony poprzez ograniczenia jego kompetencji, zmiany jego składu oraz sposobu wyboru sędziów, a także permanentny proces zmian konstytucji, realizacja modelu liberalno-demokratycznego konstytucjonalizmu stała się niezwykle trudna ${ }^{21}$.

Obecny stan rzeczy - deklarowana i zapisana w konstytucji ochrona praw podstawowych przy jednoczesnym faktycznym jej ograniczeniu — jest, jak się zauważa, efektem serii sprytnych kroków podjętych przez rząd węgierski w celu jednoczesnej zmiany konstytucjonalizmu węgierskiego oraz zachowania dobrych relacji z Unią Europejską. Charakterystyczna była reakcja węgierskiego rządu na

18 M. Bankuti, G. Halmai, K.L. Scheppele, op. cit.

19 P. Sonnevend, A. Jakab, L. Csink, op. cit.

20 Ibidem, s. 107.

21 Ibidem, s. 108. 
zalecenia Komisji Weneckiej. Jak się zauważa, rząd węgierski pozornie zastosował się do zaleceń, faktycznie jednak, powołując się na nową konstytucję, utrzymał wprowadzone zmiany, ograniczające kompetencje sądu konstytucyjnego oraz niezawisłość sędziowską 22.

Zmiany te zajęły na Węgrzech trzy lata. Jednak to, że dokonywane były w zasadzie w zgodzie z konstytucją uchwaloną przez konstytucyjną większość parlamentarną, przy zachowaniu procedur tworzenia prawa, a jednocześnie stosowaniu wspomnianych kruczków i sposobów, wskazuje, iż, jak podkreślono, na Węgrzech mamy do czynienia ze swego rodzaju prawną hipokryzją.

W odróżnieniu od Węgier, w Polsce zmiana porządku konstytucyjnego dokonywana jest poza obowiązującą konstytucją. Jest ona dokonywana $\mathrm{w}$ tempie niezwykle szybkim, ma charakter brutalny, przybierając formę swego rodzaju blitzkrieg. Towarzyszy temu lekceważenie zaleceń Komisji Weneckiej oraz specyficzna, konfrontacyjna retoryka.

Jak już wspomniano, mając poparcie nieprzekraczające 19\% ogółu wyborców, partia Prawo i Sprawiedliwość wraz z koalicjantami uzyskały w parlamencie większość, wystarczającą do uchwalenia każdej ustawy. Z możliwości tej zwycięska koalicja korzysta bez ograniczeń, przeprowadzając rodzaj kontrrewolucji, a zatem uchwalając w szybkim tempie i w wielkiej liczbie prawo istotnie zmieniające porządek konstytucyjny, niezależnie od tego, iż sama konstytucja pozostaje niezmieniona. Nie będę przytaczać kolejnych, dobrze znanych kroków podjętych w tym celu, chciałabym jednak zwrócić uwagę na cechy charakterystyczne procesu konstytucyjnej kontrrewolucji w Polsce. Zmiany te rozpoczął atak na Trybunał Konstytucyjny. Celem było ubezwłasnowolnienie Trybunału, co dokonało się w ciągu roku. Obecnie, w styczniu 2017 roku, Trybunał sądzi w dużej części w nowym składzie ( 8 sędziów wybranych przez poprzedni Sejm, 7 przez obecny), jego prezesem jest była sędzia sądu rejonowego (która sama zadecydowała o własnym wyborze), sędziowie prawidłowo wybrani przez poprzedni parlament nie zostali zaprzysiężeni przez Prezydenta RP, inni sędziowie wysyłani są na przymusowe urlopy, a Prokurator Generalny/Minister Sprawiedliwości kwestionuje prawidłowość wyboru kolejnych trzech sędziów wybranych do Trybunału w roku 2010. Ponadto, o publikacji wyroków Trybunału decyduje premier, niektóre istotne wyroki nadal nie są publikowane, w tym wyroki z 3 grudnia 2015 roku oraz 9 marca 2016 roku, a zatem wyroki orzekające niekonstytucyjność nowo uchwalonych ustaw regulujących działalność Trybunału.

Nie trzeba dodawać, iż z punktu widzenia liberalno-demokratycznego porządku konstytucyjnego rola sądu konstytucyjnego w zróżnicowanym współczesnym społeczeństwie jest nie do przecenienia. Sąd tego rodzaju jest nie tylko instytucją kluczową dla urzeczywistnienia zasady rządów prawa, kontroli procesów tworzenia prawa z punktu widzenia jego zgodności z konstytucją, lecz jest to

\footnotetext{
22 Ibidem, s. 112.
} 
także instytucja, dzięki której możliwa jest racjonalizacja systemu sprawowania władzy oraz kształtowania się konsensusu w pluralistycznym i kompleksowym społeczeństwie współczesnym, w którym ścierają się różne systemy wartości, różne racje i dyskursy. W krajach Europy Środkowo-Wschodniej rola sądownictwa konstytucyjnego jest jeszcze bardziej znacząca — podobnie jak Sąd Konstytucyjny w Niemieckiej Republice Federalnej po II wojnie światowej, sądownictwo konstytucyjne w Europie pokomunistycznej miało stanowić tamę dla odrodzenia się dyktatury, najważniejszą instytucję samobroniącej się demokracji. W roku $2016 \mathrm{w}$ Polsce tama ta została zniszczona.

Proces destrukcji porządku liberalno-demokratycznego wyznaczają kolejne ustawy uchwalane przez większość parlamentarną: ustawa o służbie cywilnej, ustawy o policji, o mediach publicznych (obecnie narodowych), o prokuraturze, a także ustawa o obrocie ziemią rolną. Wkrótce ograniczeniu ulegnie niezawisłość wymiaru sprawiedliwości. A zatem kontrrewolucja wymierzona została w kanon liberalno-demokratycznego konstytucjonalizmu: zasadę trójpodziału władz, zasadę wzajemnego równoważenia się władz — checks and balances (w Konstytucji Rzeczypospolitej Polskiej w art. 10 ust. 1 jest to zasada podziału i równowagi władzy ustawodawczej, władzy wykonawczej i władzy sądowniczej), niezawisłości sędziowskiej, ochronę praw podstawowych (w postaci inwigilacyjnych uprawnień policji) czy podstawowych wolności, takich jak wolność mediów, a ostatnio wolność zgromadzeń czy wyrażania poglądów i opinii.

Wszystkie te działania mają miejsce w sytuacji jawnego lekceważenia procedur tworzenia prawa (powtarzanie ważnych głosowań w komisjach, gdy ich wynik jest niekorzystny dla większości parlamentarnej), obyczajów parlamentarnych (wyłączanie mikrofonów posłom opozycji przez marszałka sejmu) oraz zwykłej przyzwoitości (okłamywanie opinii publicznej). Towarzyszy temu, jak wspomniano, specyficzny język debaty publicznej, szczególnego rodzaju nowomowa odwracająca znaczenia pojęć i słów, bezpardonowe obrażanie opozycji zarówno parlamentarnej, jak i pozaparlamentarnej, odwoływanie się do określeń i metafor walki. Można zatem powiedzieć, iż wraz z destrukcją liberalno-demokratycznego porządku konstytucyjnego destrukcji ulega funkcjonowanie sfery publicznej na płaszczyźnie instytucjonalnej, aksjologicznej oraz dyskursywnej.

Rzeczywista hierarchia władzy stanowi kolejny, niezwykle istotny wskaźnik stosunku do zasad i norm ustrojowych demokracji parlamentarnej. Jak wspomniano, lekceważenie prawa i zasad ustrojowych widoczne jest w tym, iż największą władzę faktyczną, rozumianą jako moc wymuszania posłuchu dla swoich decyzji, ma polityk, który jest szeregowym posłem, a zarazem przewodniczącym partii mającej większość w parlamencie. Nie będąc zatem członkiem rządu i nie sprawując żadnej funkcji państwowej, polityk ten nie ponosi żadnej politycznej odpowiedzialności za prawo, które stanowione jest pod jego wpływem, z jego woli. Z kolei faktyczna władza przewodniczącego partii przypomina władzę pierwszych sekretarzy partii komunistycznych, co wielokrotnie było przedmiotem debat pu- 
blicznych. W tym zakresie sytuacja w Polsce zasadniczo różni się od sytuacji na Węgrzech. W Polsce bowiem faktyczna władza jednostki jest władzą nieformalną i nie ma podstaw ustrojowych. A zatem w Polsce kształtuje się szczególny model władzy: nie jest to bowiem statystyczna demokracja sterowana, ale taka, której nieformalne sterowanie nie ma podstaw prawnych.

Wypada tu podkreślić polaryzację społeczeństwa. Z jednej strony, obserwujemy wysokie społeczne poparcie dla rządów Prawa i Sprawiedliwosci oraz znaczne obniżenie społecznego zaufania do instytucji będących skądinąd przedmiotem stałej krytyki w mediach państwowych (określanych obecnie w Polsce jako narodowe). I tak, zaufanie do sądów powszechnych oscylowało w Polsce w ostatnich latach wokół $50 \%$, podczas gdy zaufanie do Trybunału Konstytucyjnego było wysokie i wynosiło około $70 \%$. Obecnie, w świetle ostatniego sondażu CBOS, zaufanie do Trybunału znacząco spadło i jest znacznie niższe aniżeli zaufanie do sądów powszechnych ${ }^{23}$.

$Z$ drugiej strony, bardzo wyraźny jest społeczny sprzeciw wobec demontażu demokratyczno-liberalnego konstytucjonalizmu. W demonstracjach organizowanych przez spontanicznie tworzący się ruch Komitet Obrony Demokracji często uczestniczy kilkadziesiąt tysięcy osób, a w demonstracjach sprzeciwiających się całkowitemu zakazowi aborcji, które odbyły się w całej Polsce, uczestniczyło kilkaset tysięcy osób, nie tylko kobiet.

\title{
3. SYNDROM WSCHODNIOEUROPEJSKI: NIHILIZM AKSJOLOGICZNO-PRAWNY A NADPRODUKCJA PRAWA
}

\author{
Jest rzeczą nader dla każdego niedogodną, \\ by jego sprawa sądzona była wedle praw, \\ z którymi nie sposób się zapoznać 24 .
}

Nihilizm aksjologiczno-prawny nie przeszkadza, jak się okazuje, olbrzymiej produkcji prawa, swego rodzaju „powodzi” nowych przepisów, ustaw i aktów prawnych wykonawczych. Można wręcz zaryzykować tezę, iż pustka aksjolo-

23 Jak wskazuje analiza danych dotyczących zaufania do wymiaru sprawiedliwości, w Polsce jest ono niskie w porównaniu z innymi krajami europejskimi, jest jednak znacząco wyższe w odniesieniu do innych instytucji, przede wszystkim politycznych. Wśród sądów najwyższym zaufaniem cieszyły się Sąd Najwyższy oraz Trybunał Konstytucyjny. Badania prowadzone były w 2009 roku na ogólnopolskiej próbie reprezentatywnej 1500 respondentów, na zlecenie Krajowej Rady Sądownictwa. Por. G. Skąpska, G. Bryda, Apolityczność czy sprawiedliwość proceduralna? Zaufanie do sadowego wymiaru sprawiedliwości na tle innych instytucji publicznych $w$ Polsce, ,Studia Socjologiczne" 2013, nr 1, s. 80 n. Również w świetle niedawnego sondażu przeprowadzonego przez CBOS widać, że zaufanie do sądów jest w Polsce znacząco wyższe aniżeli zaufanie do instytucji politycznych. Sądom ufa 45\% respondentów (M. Grabowska, K. Pankowski, Wybory 2015 w badaniach CBOS, Opinie i diagnozy Nr 33, Centrum Badania Opinii Społecznej, Warszawa 2015).

${ }^{24}$ L.L. Fuller, Moralność prawa, przeł. S. Amsterdamski, Warszawa 1978, s. 70. 
giczna, brak uznania dla zasad i wartości tworzących głębokie, aksjologiczne podłoże rządów prawa i konstytucjonalizmu, jest wypełniana niezliczoną liczbą przepisów tworzonych $\mathrm{w}$ pośpiechu, byle jak, ustaw i rozporządzeń z góry skazanych na nieskuteczność. Jak wskazują dane gromadzone przez Barometr Prawa tworzony przez firmę Grant Thornton, zajmującą się monitorowaniem produkcji prawa w Polsce, od wielu już lat obserwujemy nadprodukcję prawa - w latach 2012-2014 weszło w Polsce w życie pięćdziesięciosześciokrotnie więcej przepisów niż np. w Szwecji. W ciągu ostatnich lat jednak nadprodukcja ta przybiera formę dość kuriozalną, prawo jest produkowane wręcz na skalę przemysłową w głównej mierze dzięki zastosowaniu szybkiej ścieżki legislacyjnej, a więc inicjatywy poselskiej. Oznacza to tworzenie prawa bez konsultacji i bez namysłu. Zgodnie z danymi tej firmy Polska jest w Unii Europejskiej wręcz liderem w produkcji prawa. W raporcie opublikowanym w roku 2016 czytamy, iż kolejny rok 2015 — zapisał się w historii polskiego prawodawstwa rekordową ilością nowego prawa - w życie weszło wtedy 29,8 tysięcy stron maszynopisu nowego prawa w postaci 2372 ustaw i rozporządzeń. Prawo to, tworzone w pośpiechu, cechuje się wręcz ,rozchwianiem”, jak formułują to autorzy raportu. Jest to najbardziej chwiejne prawo w polskiej historii. W świetle analiz wspomnianej firmy polski przedsiębiorca lub konsument, który chciałby być na bieżąco ze zmianami legislacyjnymi, musiałby każdego dnia czytać średnio 103 strony aktów prawnych.

Kolejny rok - 2016 - zapisuje się w historii Polski nie tylko z powodu destrukcji liberalno-demokratycznego konstytucjonalizmu, lecz także ustanowienia przez obecnie rządzącą partię kolejnego rekordu w produkcji prawa. Raport za rok 2016 nie jest jeszcze opublikowany, lecz w świetle już dostępnych danych można stwierdzić, że jedynie w trzecim kwartale roku 2016 weszło w życie 5300 stron nowych ustaw i rozporządzeń. Jakość tego nowego prawa jest obecnie analizowana, a w ciągu 11 dni nowego już roku 2017 weszło w życie 67 aktów prawnych ${ }^{25}$.

Dane te $\mathrm{z}$ jednej strony są zatrważające, $\mathrm{z}$ drugiej jednak potwierdzają tezę o zaniku jakichkolwiek wartości wiązanych z prawem, nawet najbardziej rudymentarnych, a więc jego stabilności i przewidywalności, a także o zupełnym lekceważeniu czy też niezrozumieniu funkcji prawa w gospodarce, szeroko rozumianym obrocie oraz ogólnie w społeczeństwie. Jeżeli w odniesieniu do procesów destrukcji konstytucjonalizmu można mówić o pustce aksjologicznej w sferze publicznej, to dane dokumentujące zalew, a nawet powódź byle jakiego prawa, którego adresaci nie są w stanie poznać, świadczą o tym, iż polski prawodawca

25 www.rp.pl/Prawo-dla -Ciebie/302259910; Barometr stabilności otoczenia prawnego w polskiej gospodarce Edycja 2016, https://static.pb/.../ 2912 -raport-gt-barometr-stabilnosciotoczenia-prawnego-2016); http://www.rp.pl/spor-o-trybunal-konstytucyjny/307229923; www. rp.pl/Prawo-dla -Ciebie/302259910; por. także Barometr stabilności otoczenia prawnego w polskiej gospodarce Edycja 2016, https://static.pb/.../ 2912 -raport-gt-barometr-stabilnosci-otoczeniaprawnego-2016 (dostęp: 12.01.2017). 
zupełnie lekceważy lub działa w kompletnej nieświadomości tego, co Lon Fuller określił wewnętrzną moralnością prawa ${ }^{26}$. Towarzyszy temu dążenie, w trudno zrozumiały sposób, do regulacji prawnej wszystkiego, co się da, w sposób nie tylko drobiazgowy, ile niespójny i odbiegający od rzeczywistych potrzeb. Ta smutna konstatacja pogłębia jedynie wnioski o rozdźwięku między swoistą kulturą prawną polskiego prawodawcy (lub raczej brakiem kultury prawnej) a standardami przyjętymi w demokratycznych państwach prawnych. Ponieważ, jak podkreślono, adresaci nie są w stanie zapoznać się z obowiązującym prawem ze względu na jego ilość oraz zastosować się do niego ze względu na jego złą jakość, powódź prawa jest także niemoralna społecznie, a zatem zewnętrznie, stawiając adresatów w sytuacji niemożliwej do zrealizowania i narażając ich na negatywne konsekwencje. W taki oto sposób zasada państwa prawa ulega dalszemu wypaczeniu i nabiera swoistego znaczenia państwa produkującego prawo w wielkiej ilości, ze szkodą dla jego adresatów. Ten brak poszanowania fundamentalnych zasad i wartości związanych z koncepcją państwa prawa, przy jednoczesnej nadprodukcji prawa, stanowi wskaźnik symptomatycznego lekceważenia zarówno wartości prawa, jak i fundamentalnego lekceważenia obywateli, co składa się na swoisty syndrom wschodnioeuropejski. Kolejnym elementem tego syndromu jest brak kultury demokratycznej, co jest widoczne we wspomnianym tu uproszczonym, a nawet prymitywnym pojęciu demokracji jako całkowitej władzy statystycznej większości, która może uchwalić każdą ustawę i wprowadzić każdą reformę błyskawicznie oraz bez konsultacji, lekceważąc konstytucję i prawa obywateli.

\section{O DUCHU PRAWA I PUSTCE AKSJOLOGICZNEJ W ŚRODKU EUROPY}

Przypadki Polski i Węgier wpisują się w szerszy kontekst kryzysu liberalnodemokratycznego konstytucjonalizmu, nie tylko w Europie Środkowo-Wschodniej. W nawiązaniu do tego kryzysu w tzw. nowych demokracjach, które jeszcze niedawno sprawiały wrażenie demokracji już skonsolidowanych, przypominane są teorie o swoistej próżni aksjologicznej charakterystycznej dla tego regionu Europy. Społeczeństwa Europy Środkowo-Wschodniej w drodze naśladownictwa tworzyłyby zatem systemy mające formę (np. liberalno-demokratycznych systemów konstytucyjnych) niewypełnioną treścią znaczeń i wartości ${ }^{27}$. Region ten w związku z tym miałby nie być ani Wschodem, ani Zachodem, lecz raczej swego rodzaju labilną przestrzenią, oscylującą między Wschodem i Zachodem, w zależ-

${ }^{26}$ L.L. Fuller, op. cit.

27 B. Bugarić, op. cit. 
ności od aktualnego układu sił, ogólnych tendencji oraz partykularnych interesów. Obecnie, jak zwraca się uwagę, „wiatr wieje ze Wschodu”28.

Zwrot w procesie demokratyzacji i formowania się liberalno-demokratycznego konstytucjonalizmu należy więc rozważyć w szerszym kontekście pozytywnego i negatywnego układu odniesienia, a zatem czynników decydujących o tym, od czego społeczeństwa się odcinają oraz o tym, do czego dążą. Owe układy odniesienia mogą mieć charakter historyczny i diachroniczny, w postaci odcięcia się od przeszłości czy też dążenia do realizacji zaplanowanej wizji przyszłości, jak i geograficzny, w postaci przesunięcia się z jednej strefy wpływów do innej — ze Wschodu na Zachód lub przeciwnie. Pierwotny, dość powszechny, ale jak się okazuje - nietrwały konsensus w Europie Środkowo-Wschodniej ukształtował się w opozycji do rzeczywistości, jaka tworzyła negatywny układ odniesienia — obywateli i rządy jednoczyła idea ,przeciw” temu, co odrzucali i do czego nie chcieli wracać. Odcięcie się od totalitarnej przeszłości było więc tym wydarzeniem, które wyznaczało podstawową różnicę między starym a nowym, podstawowy krok w procesie kształtowania systemu liberalnego i demokratycznego w opozycji do systemu totalitarnego. Odcięcie się od przeszłości stanowiło podstawę ukształtowania się swoistego konsensusu wokół negacji. Z tego powodu, jak się podkreśla, nowe konstytucje były „konstytucjami strachu” przed tym, iż stary system może powrócić ${ }^{29}$. Społeczeństwa te miały również pozytywny układ odniesienia w formie liberalnych demokracji zachodnich oraz demokratyczno-liberalnych konstytucji. Takim pozytywnym układem odniesienia była Unia Europejska. Stąd wielkie poparcie dla członkostwa w UE oraz dla instytucji unijnych, przynajmniej w Polsce. Członkostwo w Unii stanowiło finalny etap drogi ze „Wschodu” na „Zachód".

Obecnie pozytywny układ odniesienia stracił swą charyzmatyczną siłę przyciągającą - ekonomiczne kłopoty Unii, Brexit, niekontrolowany napływ imigrantów, wzrastające nacjonalizmy w państwach-członkach tzw. starej Unii powodują iż to, co miało stanowić cel dążeń, a zatem „normalne życie, tak jak w Europie”, staje się coraz bardziej problematyczne. Symptomatyczny jest stosunek polskich władz do zaleceń Komisji Weneckiej i Komisji Europejskiej, dotyczących Trybunału Konstytucyjnego. Inaczej niż na Węgrzech, władze w Polsce, a w szczególności przywódca partii rządzącej, zupełnie lekceważą te zalecenia.

Jednocześnie również i $\mathrm{w}$ tym regionie nie wszędzie ataki na konstytucjonalizm w jego liberalno-demokratycznym rozumieniu przybierają tak dramatyczną formę, nie wszędzie są one tak brutalne i intensywne, jak w Polsce. W innych krajach regionu obserwujemy raczej symptomy znużenia społeczeństw oraz wycofania się ze sfery publicznej, na co wskazuje niska frekwencja w wyborach

28 Ibidem, s. 239.

29 A. Sajo, Limiting Government. An Introduction to Constitutionalism, Budapest-New York 1999. 
parlamentarnych, jak na Litwie w roku 2016, w kolejnych dochodzą do władzy nieoczekiwane koalicje, w innych z kolei wzrasta nepotyzm i korupcja — wielkie wyzwania dla procedur demokratycznych, równości, transparentności oraz ochrony praw obywatelskich. Przypadek Polski jest jednak dość szczególny ze względu na to, iż, jak wspomniano, wydarzenia lat 80. i 90. w Polsce zapoczątkowały przemiany w całym regionie. Przebieg i sukces transformacji w Polsce, sukces instytucji odpowiedzialnych za implementację zasady państwa prawa, w tym przede wszystkim działanie Trybunału Konstytucyjnego czy Rzecznika Praw Obywatelskich, stały się wzorcami dla innych państw regionu, pozytywnym układem odniesienia, tym razem dla kolejnych ,nowych demokracji”. Tym bardziej symptomatyczny jest demontaż Trybunału oraz dalsze kroki w kierunku budowy swoistego ustroju politycznego opartego na woli jednostki oraz czysto fasadowej demokracji „sterowanej” przez nieformalnego przywódcę.

Jak wskazują opisane tu procesy $\mathrm{i}$ wydarzenia istotnie zarówno w pierwsza faza przemian, a zatem faza „legalnych rewolucji” jak i wydarzenia współczesne wskazują na znaczną aksjologiczną i poznawczą lukę charakteryzującą przede wszystkim proces tworzenia podstaw nowego ustroju, tworzenia prawa oraz stosunek do fundamentalnych instytucji gwarantujących urzeczywistnienie zasady państwa prawa. W fazie pierwszej luka ta polegałaby na swego rodzaju oportunizmie po stronie ustawodawcy, na braku poznawczej i moralnej odwagi ukarania winnych i zadośćuczynienia pokrzywdzonym przez poprzedni system, na czysto literalnej interpretacji prawa, ograniczeniu się do rudymentarnych wartości stałości i przewidywalności prawa, również w zakresie praw obywateli, ale nie np. obywateli pozbawionych własności przez poprzedni system, i nieuwzględnieniu społecznych roszczeń do sprawiedliwości i słuszności przyjętych rozwiązań w postaci uchwalanego prawa oraz podejmowanych na jego podstawie decyzji, orzeczeń i wyroków.

W obecnej fazie natomiast widoczny jest zdecydowany krok w tył: nawet te rudymentarne wartości, wiązane z zasadą państwa prawa, są w sposób brutalny niszczone, podobnie jak fundamentalne prawa obywateli i zbiorowości. Należy dodać, iż kolejne kroki podejmowane przez obecną parlamentarną większość oznaczają likwidację następnej fundamentalnej zasady związanej z koncepcją państwa prawa, a więc niezawisłości sędziowskiej.

Podobnie aksjologiczna i poznawcza luka cechuje samo rozumienie demokracji, tak jak jest ono obecnie propagowane i realizowane przez większość parlamentarną. Wspomniane uproszczone rozumienie demokracji jako rządów statystycznej większości, której decyzje są sterowane przez wolę jednostki przywódcy partii politycznej, mogą łamać każde prawo fundamentalne, każda zasadę konstytucyjna, niszczyć instytucje gwarantujące funkcjonowanie porządku konstytucyjnego, jeśli ma to służyć politycznym celom owej statystycznej większości, zgodnie z zasadą „zwycięzca bierze wszystko”. To rozumienie demokracji dalekie jest od rozumienia demokracji konstytucyjnej we współczesnym świecie. 
Można tutaj jedynie powtórzyć, iż „Prawdziwa demokracja jest to [...] demokracja wspólnotowa, gdzie decyzja większości jest legitymizowana tylko wtedy, gdy jest to większość w ramach wspólnoty równych" ${ }^{30}$, a zatem gdzie szanowane są prawa mniejszości oraz poszczególnych jednostek, zgodnie z konstytucyjną zasadą ochrony godności osoby ludzkiej (art. 30 Konstytucji Rzeczypospolitej Polskiej z 1997 roku).

W Polsce, jak i na wspomnianych tu jako imitowany model Węgrzech, tego rodzaju kontrrewolucyjne zmiany nie byłyby możliwe, gdyby nie ludzie, którzy je przeprowadzają. Dlatego zmianom instytucji towarzyszy przeprowadzana na wielką skalę wymiana personelu. Ma ona na celu obsadzenie ważnych pozycji w wymiarze sprawiedliwości, urzędach państwowych, spółkach skarbu państwa, mediach publicznych, a obecnie też w samorządach, przez osoby, które swoją pozycję zawdzięczają nie tyle kwalifikacjom merytorycznym, ile partii rządzącej, a zatem bez zastanowienia wykonają każdą jej decyzję.

\section{FROM „LEGAL REVOLUTION” TO COUNTERREVOLUTION. CRISIS OF LIBERAL-DEMOCRATIC CONSTITUTIONALISM IN POLAND}

\section{Summary}

This paper debates the crisis of the rule of law and liberal constitutionalism with regard to processes and events in Poland after the parliamentary elections in 2015. I will shortly debate the previous events in Hungary - a model for actions undertaken in Poland. In the first part this paper debates on the concept of "legal revolutions" which took place in the East Central Europe in 1989. They succeed in the institutionalization of the rule of law and liberal-democratic constitutionalism. The second part of the paper presents the swift, ruthless and brutal destruction of the rule of law. In the third part the "flood" of legal regulations, especially in the domains of economic transactions is shortly presented, and the part four debates cultural contexts of the current counterrevolutions. Here axiological foundations of liberal-democratic constitutionalism and the rule of law are discussed, and the issues of legal hypocrisy and legal nihilism in the context of Eastern European Syndrome are presented.

${ }^{30}$ R. Dworkin, A Bill of Rights for England: Why British Liberty Needs Protection, London 1990, cyt. za: T.T. Koncewicz, “Court-packing” in Warsaw: The Plot Tickens, ,, Verfassungsblog on matters constitutional" 18.12.2015, http://verfassungsblog.de/court-packing-in-warsaw-the-plotthickens/. 